Brandeis | иввая

brandeis.edu/j-caste
CASTE: A Global Journal on Social Exclusion

Vol. 2 No. 2 pp. $295-314$

October-November 2021

ISSN 2639-4928

https://doi.org/10.26812/caste.v2i2.306

\title{
Ethnic Identity, Discrimination and the Shaping of Remittance Culture in Ghana
}

\author{
Joseph Kweku Assan'
}

\begin{abstract}
This article examines birth-based structures and endogenous practices in the migration patterns of two ethnic groups in southern Ghana. The sampled ethnic groups for this study are the Akuapems from the Akan ethnic group located in the Akuapem North district and the Ada/Dangme's from the Ga-Adangme ethnic group located in the Shai-Osudoku District and the Ningo-Prampram District (formally known as Dangme West District). The article discusses how ethnic identity influences remittance patterns and the utilization of sampled migrants' home districts. Data from a questionnaire survey, interviews, and focus group meetings informed the study. The study results indicate a strong relationship between patterns, practices, and utilization of remittances and the respective norms and social values embedded within the migrants' ethnic identity. The research also shows that migrants from ethnic groups with strong internal cohesion and less assimilation remit more than those from more ethnically heterogeneous groups. The study found that migrants from matrilineal ethnicity remit more than those of the patrilineal group. Ethnic values also shape the type of investments that internal migrants and their families may pursue. The research contributes to the debate on agency and endogenous development within birth-based structured societies. It also advances the discourse on birthbased identities, marginalization, and informal poverty reductions mechanisms and strategies.
\end{abstract}

\section{Keywords}

Ghana, birth-based identity, ethnicity, social mobility, internal migration, youth, remittances

\footnotetext{
'Professor, Center for Global Development and Sustainability, Heller School for Social Policy and Management, Brandeis University, Waltham, MA, USA

E-mail: joeassan@brandeis.edu
}

(C) 2021 Joseph Kweku Assan.This is an open access article distributed under the terms of the Creative Commons Attribution License, which permits unrestricted use, distribution, and reproduction in any medium, provided the original author(s) and source are credited. 


\section{Introduction}

The intersection of birth-based structures, social vulnerability and inclusion, and livelihood options/opportunities of minority groups have gained importance in the development policy and social justice literature (Crossman, 2020; Contzen; and Müller-Böke, 2014). There is a belief that the sending and subsequent utilization of remittances could be shaped by the birth-based identity [like caste or ethnicity] and socio-cultural values of senders and recipients' families and communities (LópezAnuarbe et al., 2016). López-Anuarbe et al. (2016) further argue that birth-based identity, informed by cultural norms, embodies the collectivism and familism that characterizes remitting behavior, as they do in shaping one's agency, social identity, and family dynamics. They guide social structures and traditions of care in certain ethnic identity groups. Migration and associated remittances have always been a vital livelihood strategy, a source of income for the marginalized poor and deprived ethnic minority households, especially within birth-based structural societies in Africa with no formal welfare systems (Assan and Kharisma, 2019). Reddy (2005) also highlights the intersectionality of ethnicity, caste, and race in social solidarity struggles/support systems.

Aware of this hypothesis, this article posits that migrant household members within the same geographical area but of different ethnicity may engage in different remittance strategies and maneuvers that could be considered endogenous to the development of such societies as a result of their birth-based identities and structures. The article, therefore, seeks to examine how ethnicity as a birth-based identity of migrants influences the nature and the use of remittances in their natal communities and their subsequent development. We argue that within the internal migration and remittances framework, remittance patterns and utilization could be shaped by migrants' ethnic identity: clan norms, traditions, and cultural values and agency. Sander (2003, p. 3) defines a migrants' remittance as: "monies sent from workers who left their home village or town to work elsewhere in their home country or abroad to an individual or household". Remittance flows to sub-Saharan Africa declined by 9 percent, to $\$ 44$ billion in 2020, and is projected to decrease further by another 5.8 percent, to $\$ 41$ billion, in 2021, as a result of the Covid-19 pandemic (Usman, 2021; Brookings, 2021).

This article is organized as follows: section one presents an introduction and states the objectives of the study, while section two provides a conceptual review of ethnicity and remittances. Section three briefly introduces the study context and fieldwork strategy employed during the data collection process. Sections four and five share empirical results from both quantitative and qualitative data generated by the study and a discussion of the findings. Concluding remarks and recommendations are found in section six.

\section{Conceptualising Ethnicity and Remittances}

Reddy (2005) argues that "Caste" is frequently intertwined with that of "Race/ Ethnicity", from Max Mueller's articulation of the Aryan theory of race/ethnicity and pan-Africanist expressions of racial/ethnic solidarity with the lower castes of India, caste has frequently been redefined by being drawn into broader discourses about race 
and ethnicity. Informed by this complex history, Reddy asks how "race/ethnicity" and "caste" have come to serve as key metaphors of socio-political, and more recently, economic struggle, illuminating one another and emerging as powerful rhetorical strategies of social critique, in more global contexts.

The words race and ethnicity do not share a dictionary definition, and yet their meanings sometimes overlap, helping individuals define not just their skin tone and other physical characteristics but their ancestry and heritage as well (Dictionary. com, 2021). Ethnicity is defined by Mompati and Prinsen (2000, p. 626) as a social phenomenon concerned with negative and or positive interaction between culturallinguistic groups and generally refers to a person's affiliation with a particular ethnic group, or to their sharing qualities, characteristics, or customs of that ethnic group. According to the Phoenix Library Resources on Ethnic Identity and Diversity (2008, p. 1), "ethnicity generally refers to a person's affiliation with a particular group, or to their sharing qualities, characteristics or customs of that group". It argues that ethnic identity, however, is rather personal and individualistic with many facets based on several socio-cultural factors, including geography, nationality, ancestry, family, culture, and subculture. Nevertheless, the concept of ethnic group defies easy categorization (St-Hilaire, 2010). In his examination of ethnicity, Riggs (1997a) explained ethnicity as involving a group of people sharing the same cultural norms, based on language, customs, and ancestry. Yinger (1994) describes an ethnic group as a segment of a larger society whose members are thought, by themselves or others, to have a common culture and who participate in shared activities in which the common origin and culture are important elements (Mazzucato, 2008).

Deeply embedded in ethnicity and identity in the context of sub-Saharan Africa is the kin group. This is defined by La Ferrara (2003, p. 1730) as a "network of unilineal families that share common cultural traditions, ethnic identity and often ancestors". She argued that one is born with a given set of blood relations and cannot choose to join or leave it. La Ferrara described kin groups as an intermediate level of social organization between clans and ethnic groups. She argued that while a clan is a unilineal group of relatives living in one locality, a kin group is formed by various clans and comprises "socially recognized relationships based on supposed or actual genealogical ties" (Winick, 1956, p. 302). An ethnic group, on the other hand, "consists of several kin groups bound together by language and by common rules of social organization" (La Ferrara, 2003, p. 1732). She further explains that kinsmen are dynastically linked in such a way that status and stigma attached to parents can be transferred to their children. The motivation to remit could be described as a form of social reproduction which is embedded in the ethnic identity of the individual migrant as kin groups are expected to offer the needed support to protect the image and well-being of their members. In this article, ethnicity will refer to ethnic groups, their associated kin groups, and the values which shape their identity.

\section{Linking ethnic identity, kin groups, and remittances}

It can be argued that ethnicity and kin groups are rather contested concepts and are often misunderstood. However, it is evident that these concepts define social structure, shape actions, and influence human agency expression within many societies (Assan, 2008). Ethnic identity plays a vital role in determining social behavior and the generation of social capital, especially amongst migrants and their natal communities. Ethnic identity is also known to influence, define and govern the choices and decisions 
made in the broader context of remittances and migration (Assan and Khrisma, 2019). Ethnic groups offer solidarity mechanisms in societies with high idiosyncratic risks and create an opportunity for mutual insurance (Levitt, 1998). While several debates have been presented for the success of such mutual insurance schemes within ethnic and kin groups, reciprocity and enforcement are two main reasons which seem to stand out. Kin groups often obey the principle of collective responsibility where members of the same clan are held jointly responsible for the actions of each other and, more importantly, personal needs. For most marginalized societies, especially in developing countries, informal socio-cultural institutions established in tradition and identity are essential for providing insurance, pensions, and facilitating economic exchange and social transformation within households and communities (Lassen and Lilleør, 2006).

Nevertheless, unlike most developed societies where formal institutions of support are well structured and functional, formal institutions are weak in Africa and individuals rather negotiate their economic relationships through social institutions (Miguel and Gugerty, 2005). Rural agrarian/fishery families are believed to invest in the education of their members with the belief that they could eventually migrate to urban centers and subsequently send in remittances (Bates, 2000). Using evidence from Zambia, Bates revealed that the benefits and income of rural dwellers derived from migrants in urban areas vary with family structure and ethnicity. Conversely, while families and ethnic/kin groups are proud and willing to devote scarce resources to the upbringing and training of younger members, the younger generation also takes pride in their ability to provide for their parents/older generation (Assan, 2008). Nevertheless, with the onset of the Covid-19 pandemic, several ethnic minority migrant enterprises have been devastated. There are between 85 million to 95 million Micro, Small, and Medium Scale Enterprises in Africa who are especially vulnerable to COVID-19 mitigation measures such as social distancing, stay home orders, etc., and 75 percent saw their revenue decline by over 30 percent as of May 2020 (Brookings, 2021).

\section{Ethnicity as a social and economic tool for migrants and their communities}

Ethnic identity is considered to offer valuable internal support for socially disadvantaged groups and could be used as a coping mechanism. It is described by St-Hilaire (2001) as able to generate solidarity for socially disadvantaged groups and thereby empower them to overcome social and economic hardships. Similarly, Marquette (2007) argues that identity generally, and ethnicity specifically, serves to facilitate beneficial economic interactions that would otherwise not have taken place. He also argues that it is precisely the ability of clans or ethnic groups to levy and uphold social sanctions that sometimes make ethnicity a creative force in sub-Saharan Africa (Black et al., 2005). Lassen and Lileor (2006) revealed a strong positive relationship between the strength of an ethnic group and identity within a kin group and human capital investment decisions among its members. They also provided empirical evidence to show that such ethnic networks function better when rooted in more homogenous communities. Ethnic diversity can impinge on credit constraints, a recurring problem for most households in developing countries. Ethnicity generates and shapes the type and quality of social capital and bonding within a tribal group which may also influence risk sharing (Agarwal and Horowitz, 2002). Ethnic diversity at the village level influences the probability of gaining urban entry to the urban market as well as the enforcement of repayment of the 
implicit loan provided to migrants (Winkels, 2002). Migrants' identity and ethnicity could, to some extent, determine individuals' inclination and direction of support towards members with similar identity (Goldscheider, 1987).

\section{Internal differentiation between ethnic groups and propensity to remit}

It is thought that although several kin groups in Africa may uphold values of reciprocity and remittance, some ethnic groups are more supportive of their members than others. The difference in internal cohesion within ethnic groups has been identified as a possible contributory factor to this variation (Miguel and Gugerty, 2005). The aforementioned authors provided evidence to show that the level of heterogeneity within the migrants' native community and the kin group could serve as an important determinant of a migrants' propensity to remit family members and participate in collective action. Lassen and Lileor (2006) also showed a significant positive relationship between the proportion of households receiving remittances from children within ethnic groups with low internal fragmentation compared to ethnic groups with high internal fragmentation. In most homogenous groups, such as those with fewer dialects or operating similar norms, the average proportion of households receiving remittances from their children is higher than most heterogeneous ethnic groups and villages.

Trust in family members, trust in a fellow clan, unity of village/town, the spirit of participation in the community, group functioning, group decision-making structure, and income inequality can shape the degree to which a migrant will remit the members of extended family (Tsegai, 2007; Lassen and Lileor, 2006). This suggests that ethnic groups with intense bonding and a greater degree of trust are likely to experience more remittance behavior and could receive more remittances from migrant members (Lamphere, 2007; Tsegai, 2007). The strength of ethnic identity and values at the village level is viewed as a proxy for the density of urban networks, which are important, both for gaining urban entry and for maintaining migrants' ties with their rural home, by providing information about the family as well as monitoring that wages are remitted (Tsegai, 2007). Internal differentiation can also influence the ability of the village to levy social sanctions and enforce tribal rules, norms, and social responsibility. Nevertheless, assimilation, which St-Hilaire defines as "a process of boundary reduction that can occur when members of two or more ethnic groups meet" can weaken migrants' commitment to social values and familial norms regarding remittances (St-Hilaire, 2010, p. 1000). He argues that migrants tend to take on the behavior and practices of mainstream culture at their respective destinations and conceded that migrants might preserve their ethnic values, norms, and tight group solidarity for the benefit of the group members and relatives back home or abandon such values, including sending of remittances for the culture of the dominant social group, possibly to the detriment of ethnic groups members (Lamphere, 2007; Portes and Manning, 1991; Zhou, 1997).

It is presently perceived that remittance receivers are often better-off and could diversify their income portfolio more quickly than their peers who do not have access to this source of finance. In South Asia and sub-Saharan Africa, remittances from ruralurban migrants are overtaking incomes from agriculture in sheer size and importance. Remittances from internal migration are considered to enhance household well-being and facilitate socio-economic transformation through higher incomes, improved 
health, nutrition, better housing, and investment in production (Assan et al., 2018). As persistent socio-economic and structural problems continue to depress the levels of wages and availability of work, one of the key issues of concern for academics and policymakers in developing countries is how remittances are used and the local impact within different ethnic groups (van der Geest, 2003; Deshingkar and Anderson, 2004). Therefore, it is imperative to ascertain how birth-based structures, such as migrants' ethnicity, shape and inform the remittance and utilization pattern.

\section{Study Context and Fieldwork Strategy}

\section{Ethnicity in Ghana}

It is estimated that there are approximately 100 different ethnolinguistic groups to which Ghanaians belong. Ethnic groups in Ghana are generally categorized along tribal lines, with each composed of sub-ethnic and kin groups. Each ethnic group has its dialect, cultural identity, practices, and beliefs, which shape how members express their institutional and human agency (Giddens and Pierson, 1997; Henze 2005). The predominant ethnic groups are the Akans (49.1 percent), followed by the Mole Dagbani (16.5 percent), Eve (12.7 percent), and Ga-Adangme (8 percent) (GSS, 2000). Although geographically located next to each other, the sampled districts belong to two different ethnic groups, have different social, economic, and political traditions and norms, and have large rural farming communities (Agyepong, 1997; Middleton, 1979; Benneh, 1971, 1979). Communities in these districts are considered income poor (live on less than 1 dollar a day and are experiencing increasing out-migration). As a result, the major economic and socio-cultural activities undertaken by households in the study districts are perceived to be undergoing extensive transformation through the use of remittances from out-migrants.

\section{The Akuapems (Akan) Ethnic Group}

The origin of the Akan people of Ghana, although the subject of some controversy, has been traced to as far as the Tigris and Euphrates in Mesopotamia. It is thought that they migrated from the ancient Negro Kingdom of the medieval Ghana Empire before settling in modern Ghana (Meyerowitz, 1952; Ghana District Repository, 2008). Meyerowitz argues that the present Akan aristocracy were the descendants of the Dia and Za (originally from Abyssinia), the Libyan Berbers, and Gera (of the Kushite stock) who emigrated to the South when the Arabs conquered North Africa. The major tribal groups within the Akan ethnic group include the Fantes, Akuapems, Kwahus, Asante, Akyims, Denkyiras, and the Akwamus. Within these groupings, there are subdivisions, as in kin, clans, and families.

\section{Social organization}

Ghana District Repository explains that the most important of the social set of the Akans are in the identical exogamous matrilineal clans and patrilineal groupings. Every Akan group is divided into seven or eight patrilineal warrior groups. At birth, every Akan child belongs to the mother's clan (matrilineal), although in predominantly male institutions such as warrior groups, every male belongs to the fathers' warrior group. The Akan family consists of all those who trace their lineage from one maternal relative. Inheritance is, therefore, through the mothers' lineage with both 
maternal and patrilineal relatives belonging to the external family and responsible for ensuring social and economic harmony in the family. The combination of matrilineal and patrilineal systems of inheritance as well as their aristocratic heritage gives the Akans a strong sense of social cohesion with tribal groups and responsibility towards both parents but support is more inclined towards the mother. "Wherever they may live, they regard their towns/villages as the hometown and return whenever they can, ultimately at their death to be buried with as elaborate a funeral as can be afforded" (Middleton, 1979, p. 248).

\section{The Dangmes (Ga-Adangme) Ethnic Group}

According to the Ghana District Repository, the residents of Shai-Osudoku and Ningo-Prampram Districts (formally Dangme West) traditionally belong to the ethnic Ga-Adangme group in Ghana. They are believed to have migrated from the eastern part of West Africa, which often refers to areas around the present Yoruba territory in present-day the Federal Republic of Nigeria. The Ga-Adangbe people inhabit the Accra Plains (Dickson and Benneh, 1988). Although European academic records suggest that the Gá-Adangme has occupied their present homeland for about five hundred years or some seventeen generations, oral tradition indicates that they have occupied the land much longer. The Adangbe group is found to the east, the Ga groups, to the west of the Accra plains and coastlands (British Library of Congress, 1994). The modern Adangbe include the people of Ada/Dangme, Shai, La, Ningo, Kpone, Osudoku, Krobo, and Gbugble, who speak different dialects and are believed to have been culturally influenced by their neighboring Guan and Ewe groups in south-eastern Ghana and have therefore experienced significant cultural assimilation which is evident by internal heterogeneity compared to the Akuapems.

\section{Social organization}

The nucleus of the Ga-Adangbe social set-up is the family. The family plays a vital role in both social and economic engagements; for example, members are obliged to contribute towards the burial of dead members. The Ga-Adangmes operate a patrilineal system of inheritance and inheritance is through the fathers' family line. Fathers, therefore, play an important role in the nucleus and extended family. Puberty rites feature prominently in the culture of this ethnic group and these are obligatory for girls. They are taken through the Dipo puberty rites during which they are expected to dance half-naked in public. Puberty rites initiate adolescent girls into adulthood. As this is obligatory, girls who do not undergo such initiation before getting pregnant could be banished from the community. To avoid such puberty rites, individuals and families may migrate to urban locations. Also, males are expected to pay dowry to their brides. This is also considered as an important reason for migration among young males.

\section{Field Work Strategy}

In each of the study districts, fifty heads of households (twenty-three males and twentyseven females in Akuapem North; and thirty-three males and seventeen females in Shai-Osudoku and Ningo-Prampram Districts) whose members have out-migrated in the last five years were interviewed from eight communities using an exploratory and evaluative multi-stage research strategy and the respective district economic baseline 
studies and district profiles (de Haan and Zoomers, 2005; Kitchen and Tate, 2000). The study subsequently interviewed a further 170 young migrants from the sampled households in Akuapem North and Shai-Osudoku and Ningo-Prampram Districts working at various commercial centers in Accra (the administrative capital of Ghana) and Tema (the industrial capital of Ghana) using survey and snowing-balling methods. Thus, the study interviewed one hundred household heads from sixteen communities from the selected districts. The out-migrated members of the sampled households were followed to the destinations and interviewed while some of the interviews took place in the respective communities, as these individuals visited families. Focus group discussion meetings on each of the selected communities with household heads and visiting out-migrants complemented the interviews. Figure 1 shows the locations of Accra, Tema, Akuapem North District, and the Dangme West District (recently redistricted as Shai-Osudoku and Ningo-Prampram Districts) and the locations of communities that were sampled for the study. The research did not report on historical movement patterns due to the unavailability of data and adopted a socio-economic transformation approach rather than a demographic approach. The empirical findings generated from the survey, interviews, and focus group discussions with members of sampled households are discussed in section four of the article. The fieldwork was carried out over three months.

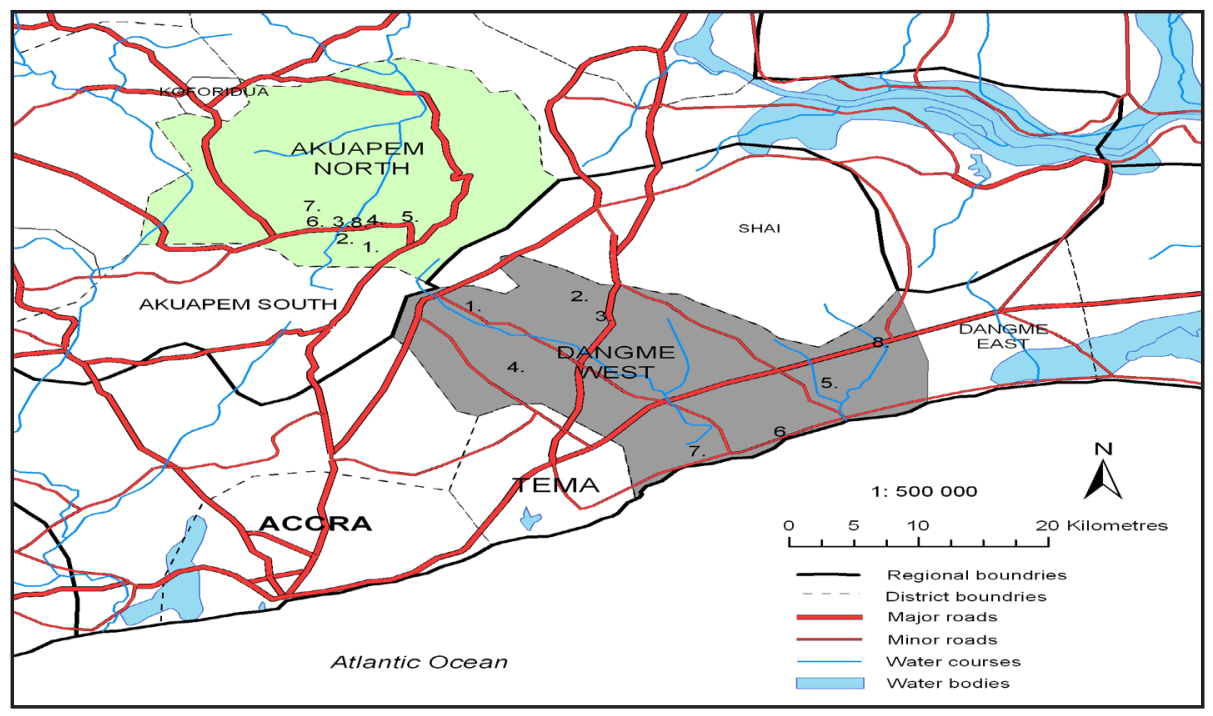

Figure I: Map of Study Districts and Sampled Communities

Source: Author, 2021. Edited by the Author from www.esri.com

\section{Characteristics of out-migrants}

The household survey shows that ninety-three households out of the total one hundred samples indicated that one or more of its members have out-migrated. The seven households without out-migrants were all located in Akuapem North District. 
The migration of household members was observed in both districts (see Table 1) of the study. A 30-year-old female migrant working in Accra but from Akuapem North attempted to identify the key reasons for the rise in out-migration in the study areas by saying:

... as a consequence of policy reforms in the agricultural sector and the harsh land-tenure systems currently in force, the need to obtain employment in the non-farm sector has driven most households members to migrate, since the prospects of working in the food-production sector and raising sufficient funds to service households needs through income from farming activities continue to appear increasingly bleak.

Table I:Age and gender of juvenile and adult out-migrated members

\begin{tabular}{|l|c|c|c|c|c|c|c|c|}
\hline $\begin{array}{c}\text { Age in } \\
\text { years }\end{array}$ & \multicolumn{3}{|c|}{ Gender of juvenile \& adult migrant members (\%) } & \multicolumn{2}{c|}{$\begin{array}{c}\text { Grand } \\
\text { Total }\end{array}$} \\
\hline & \multicolumn{3}{|c|}{ Akuapem North } & \multicolumn{3}{c|}{$\begin{array}{c}\text { Shai-Osudoku and } \\
\text { Ningo-Prampram }\end{array}$} & \multicolumn{2}{c|}{} \\
\hline & Male & Female & Total \% & Male & Female & Total \% & N & $\%$ \\
\hline$<15$ years & 2.1 & 4.3 & 6.4 & 0 & 17.1 & 17.1 & 19 & 11.1 \\
\hline $15-24$ & 14.9 & 19.1 & 34.0 & 27.6 & 39.5 & 67.1 & 83 & 48.8 \\
\hline $25-34$ & 43.6 & 12.8 & 56.4 & 10.5 & 2.6 & 13.2 & 63 & 37.0 \\
\hline $34+$ & 3.2 & 0 & 3.2 & 2.6 & 0 & 2.6 & 5 & 2.9 \\
\hline Total (\%) & 63.8 & 36.2 & 100.0 & 40.8 & 59.2 & 100.0 & & \\
\hline Total (N) & 60 & 34 & 94 & 31 & 45 & 76 & 170 & 100.0 \\
\hline
\end{tabular}

Source: Author, 202I.

The results show that out-migration within the sampled household is not genderrestricted (see Table 1). A comparison of the two districts shows that the percentage of adult-juvenile male out-migrants (63.8 percent) is higher than females (36.2 percent) in Akuapem North. It was explained that traditionally, young males from the district are given preferential formal education than females and subsequently tend to out-migrate to seek employment or further studies. On the other hand, outmigration amongst young females is more frequent (59.2 percent) than males (40.8 percent) in Shai-Osudoku and Ningo-Prampram Districts (see Table 2). According to the interviews in Shai-Osudoku and Ningo-Prampram Districts, cultural values in the Dangme traditional area encourage young females to engage in trading activities at a very early age which subsequently exposes them to migration. Again, migration also allows young females to escape or postpone mandatory puberty rites of passage ceremonies which can be costly and stressful.

\section{Ethnicity and socio-cultural differentiation}

The focus group meetings held in sampled communities in the two districts revealed contrasting ethnic and cultural practices that tend to influence migrants' patterns of remittances and their utilization. Middleton (1979) argued that Ghana's traditional system of inheritance influences migrants' social behavior and practices. 
Table 2: Ethnicity and Socio-cultural Values and Practices

\begin{tabular}{|c|c|c|}
\hline Ethics Values & Akuapems & Dangmes \\
\hline Language & $\begin{array}{l}\text { These are Akans and speak the Twi } \\
\text { dialect }\end{array}$ & $\begin{array}{l}\text { These are Ga-Adangmes and } \\
\text { speak the Ga, Krobo, and Ada } \\
\text { dialects }\end{array}$ \\
\hline System of inheritance & $\begin{array}{l}\text { The Akuapems operate a matrilineal } \\
\text { social system where the children would } \\
\text { normally belong to the mothers family } \\
\text { and are more inclined to see to the } \\
\text { welfare of the mother }\end{array}$ & $\begin{array}{l}\text { Children belong to the fathers } \\
\text { family and also the grandchildren } \\
\text { are sometimes referred to as the } \\
\text { responsibility of the grandfather }\end{array}$ \\
\hline Morality & $\begin{array}{l}\text { Considered to have high moral and } \\
\text { religious values relating to marriage and } \\
\text { sexuality }\end{array}$ & $\begin{array}{l}\text { Considered to have lesser moral } \\
\text { values relating to marriage and } \\
\text { often have more than one spouse }\end{array}$ \\
\hline $\begin{array}{l}\text { Social support } \\
\text { networks }\end{array}$ & $\begin{array}{l}\text { The matrilineal system fosters stronger } \\
\text { social networks around the mother } \\
\text { figure who is considered vulnerable and } \\
\text { requires closer support and thereby } \\
\text { draws children together as a family }\end{array}$ & $\begin{array}{l}\text { There is a weaker support } \\
\text { network as a father is often } \\
\text { considered a strong figure and } \\
\text { capable of managing the affairs } \\
\text { of the family. High incidence of } \\
\text { polygamy also means children } \\
\text { may have different mothers and } \\
\text { may not be inclined towards } \\
\text { contributing to the household } \\
\text { budget and rather cater for } \\
\text { themselves }\end{array}$ \\
\hline $\begin{array}{l}\text { Social organization, } \\
\text { housing, and } \\
\text { habitation }\end{array}$ & $\begin{array}{l}\text { Husbands may normally live separately } \\
\text { from the wife in their respective family } \\
\text { houses. More affluent families couples } \\
\text { may live together }\end{array}$ & $\begin{array}{l}\text { Husbands may live together in } \\
\text { the same compound house with } \\
\text { the different spouses and their } \\
\text { children }\end{array}$ \\
\hline Social status & $\begin{array}{l}\text { Individuals with good educational } \\
\text { backgrounds are highly regarded in } \\
\text { society }\end{array}$ & $\begin{array}{l}\text { Social status is often liked to } \\
\text { economic wealth, type of housing, } \\
\text { and or appearance }\end{array}$ \\
\hline $\begin{array}{l}\text { Rite of passage } \\
\text { rituals }\end{array}$ & $\begin{array}{l}\text { Conduct naming ceremonies for } \\
\text { newborn babies but may not insist } \\
\text { on right of passage ceremonies to } \\
\text { adulthood }\end{array}$ & $\begin{array}{l}\text { Conduct naming ceremonies } \\
\text { for newborn babies, insist and } \\
\text { practice elaborate and expensive } \\
\text { right of passage ceremonies for } \\
\text { teenage members, particularly for } \\
\text { ushering females family members } \\
\text { into adulthood (womanhood) }\end{array}$ \\
\hline
\end{tabular}

Source: Author, 202I.

A household head from Akuapem North explained that "unlike the patrilineal ethnic groups, mothers tend to be social figures that draw children together and foster stronger socio-economic ties within our ethnic group". This makes migrant children from matrilineal families more interested in and compelled by their ethnic values to support their mothers. However, in the case of Ga-Adangmes, a male household head argued that "in our traditional areas children are not obliged to support the father and are sometimes not particularly sympathetic to their cause especially in the context of polygamous households and may choose not to remit him".

There is a marked distinction in social organization between the two groups. According to a 50-year-old household head, "the permissive moral culture amongst the Dangmes means that most children grow up with step-siblings or step-parents, which tend to reduce the social cohesion and the sense of responsibility towards their 
father or other members of the household". The study also found that whereas Dangme couples traditionally reside in the same household, in the case of Akuapems, the man and woman may live separately in their respective family homes even after marriage. The woman's family and adult children eventually assume the responsibility of caring for their mother. Again, the Akuapems are traditionally expected to pay regular weekend or monthly visits to their hometown. This is consistent with the findings of Middleton (1979), as he reported on the social values of the Akuapems. This could, therefore, influence the pattern of remittances as those who are not able to make such regular visits have to send their remittances through friends and acquaintances.

It also emerged from the focus group meetings and household interviews that although physical assets and the number of children are used as indicators of wealth in both districts, the Akuapems rank individuals and households with good educational attainment highly within the society. On the contrary, the Dangmes generally identify status by contributing to social gatherings, appearance, and the number of children. The elaborate rite of passage ceremonies for children and teenagers with their attendant cost was cited as the reason why younger members migrate. A female household head from Ga-Adangme ethnic group retorted "those who are not able to meet these traditional demands and social contributions would often migrate and stay away from the family". This view is corroborated by Agyepong et al. (1997). The study was informed that these cultural norms serve as the drive or motivation for current patterns of migration and the use of remittances.

\section{Migrants Destination and Employment}

A comparison of the two districts identified a significant variation in the migration and employment activities undertaken by the two groups at their respective destinations. The household interviews revealed that the availability of jobs and laborers networks, low-cost transportation, links with relatives and friends, and the ability to speak the local dialect influenced migrants' choice of destination (for internal migration). The study observed that although some of the individual migrants traveled to other rural destinations (6.4 percent from Akuapem North and 1.3 percent from Shai-Osudoku and Ningo-Prampram Districts), the majority of the sampled migrants traveled to urban destinations in Accra and Tema. Both locations are within 60 kilometers of the two districts. While those from Akuapem North preferred to move to Accra, migrants from Shai-Osudoku and Ningo-Prampram Districts mainly traveled to Tema. These movement patterns were attributed to the traditional ethnic networks that have been built up over several years. The migrants confirmed that they rely on ethnic associations and kinsmen residents in Tema and Accra to gain employment since employment tends to be very competitive.

Half (50.6 percent) of the sampled adult and juvenile out-migrants identified by the survey are engaged in non-farm laborers and artisanship. The majority of them originate from Akuapem North (54.3 percent). Hawking, trading and lorry driving are indicated as the preferred common employment in both districts (see Table 3). Most rural-urban migrants travel to urban destinations where there are large food factories, markets, and construction sites and find work as food traders, shop assistants, food hawkers, head-loaders, ${ }^{1}$ and labourers. Tema Port and its warehouse operations also offer waged employment and short-term contracts for labourers and porters, especially for the Ga-Adangme migrants. International migration is mainly reported in the Shai-

${ }^{1}$ These are bearers who carry their loads on their heads instead of on their backs, or on a cart. 
Osudoku and Ningo-Prampram districts (26.3 percent), where youths and children travel to neighbouring countries of Ghana to join their relatives and friends who work as fishermen and fish traders, which are occupations associated with this ethnic group (see Table 3). Agyepong et al. (1997) findings on the migration of Dangme fishing households support these observations.

Table 3: Type of migration and associated employment of adult and juvenile

\begin{tabular}{|c|c|c|c|c|c|c|c|c|c|c|c|c|}
\hline \multirow[b]{3}{*}{ 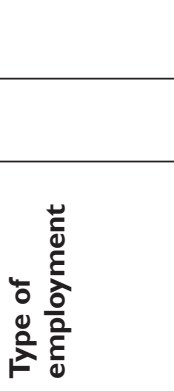 } & \multicolumn{5}{|c|}{ Akuapem North } & \multicolumn{5}{|c|}{$\begin{array}{l}\text { Shai-Osudoku and Ningo- } \\
\text { Prampram }\end{array}$} & \multirow{2}{*}{\multicolumn{2}{|c|}{$\begin{array}{l}\text { Grand } \\
\text { Total }\end{array}$}} \\
\hline & \multicolumn{10}{|c|}{$\begin{array}{l}\text { Type of migration household members (adults and } \\
\text { juveniles) } \%\end{array}$} & & \\
\hline & 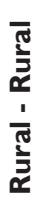 & 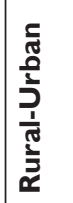 & 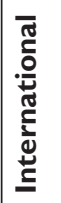 & 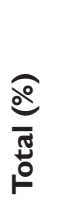 & 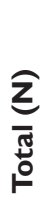 & 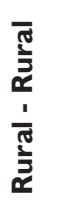 & 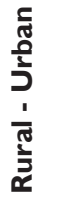 & 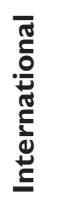 & 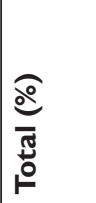 & 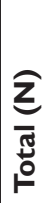 & $\stackrel{\circ}{\mathbf{Z}}$ & \\
\hline $\begin{array}{l}\text { Farm-wage } \\
\text { labor }\end{array}$ & 5.3 & I.I & 0.0 & 6.4 & 6 & 0.0 & 0.0 & 1.3 & 1.3 & 1 & 7 & 4.1 \\
\hline $\begin{array}{l}\text { Artisans } \\
\text { Non-farm } \\
\text { manual labor }\end{array}$ & I.I & 54.3 & 2.1 & 57.4 & 54 & 1.3 & 36.8 & 3.9 & 42.1 & 32 & 86 & 50.6 \\
\hline $\begin{array}{l}\text { Hawking } \\
\text { Trading } \\
\text { Lorry driving }\end{array}$ & 0.0 & 26.6 & 0.0 & 26.6 & 25 & 0.0 & 27.6 & 21.1 & 48.7 & 37 & 62 & 36.6 \\
\hline $\begin{array}{l}\text { Clerical } \\
\text { work } \\
\text { Technician }\end{array}$ & 0.0 & 9.6 & 0.0 & 9.6 & 9 & 0.0 & 7.9 & 0.0 & 7.9 & 6 & 15 & 8.8 \\
\hline Total & 6.4 & 91.5 & 2.1 & 100.0 & & 1.3 & 72.4 & 26.3 & 100.0 & & & \\
\hline Total (N) & 6 & 86 & 2 & & 94 & 1 & 55 & 20 & & 76 & 170 & 100 \\
\hline & & & & $P=0$. & & & & & $P=0.0$ & & & \\
\hline
\end{tabular}

Source: Author, 2021.

\section{Remittance Flows into Peasant Households and Communities}

All the households with migrants indicated that they receive remittances. A comparison of the cash remittances received by the two ethnic groups shows that remittances to households in Akuapem North district are a lot more $(\not 9000.10)^{2}$ than the amount received in Shai-Osudoku and Ningo-Prampram districts ( $\Varangle 5000.15)$. Besides, the average amount of money sent to the households in Akuapem North ( $\$ 210.16)$ is more than in Shai-Osudoku and Ningo-Prampram districts ( $\notin 150.15)$ (see Table 4). However, the larger standard deviation ( $\$ 580.51)$ for Akuapem North compared to Shai-Osudoku and Ningo-Prampram districts (430.49) implies that the distribution is more dispersed in the Akuapem North district and could introduce disparity in income. Hence the possibility of internal differentiation is more likely in Akuapem North (see Table 4).

${ }^{2} \$ 1$ (US Dollar) $=\varnothing 6.11$ (Ghana Cedi). 
Table 4:Amount of remittances received per annum

\begin{tabular}{|c|c|c|c|c|c|c|}
\hline \multirow[t]{2}{*}{ Period } & \multicolumn{2}{|c|}{ Akuapem North } & \multicolumn{2}{|c|}{$\begin{array}{l}\text { Shai-Osudoku and } \\
\text { Ningo-Prampram }\end{array}$} & \multirow[t]{2}{*}{$\begin{array}{c}\text { Total } \\
\text { frequency }\end{array}$} & \multirow[t]{2}{*}{ Total \% } \\
\hline & frequency & $\%$ & frequency & $\%$ & & \\
\hline $2-4 y r s$ & 22 & 51.2 & 24 & 70.6 & 46 & 59.7 \\
\hline$>4$ years & 21 & 48.8 & 10 & 29.4 & 31 & 40.3 \\
\hline Total & 43 & 100.0 & 34 & 100.0 & 77 & 100.0 \\
\hline$P=0.023$ & & & & & & \\
\hline
\end{tabular}

Source: Author, 2021.

The high remittance rate in Akuapem North was explained by the strong tribal bonds associated with the matrilineal cultural identity and the emerging competition amongst Akuapem migrants regarding support for their mothers and kin as expected in a matrilineal society. The study also informed that the presence of several ethnic/tribal associations facilitates the sending of remittances to the Akuapem area compared to the Ga-Adangmes, making it easier for migrants to send money back home. The Dangmes were, however, described as generally less patriotic and individualistic, which can be linked to their patrilineal heritage.

Table 5:Amount of remittance received per annum in cedis (GHS $\phi) 3$

\begin{tabular}{|l|c|c|}
\hline Remittances & Akuapem North (ф) & $\begin{array}{c}\text { Shai-Osudoku and Ningo- } \\
\text { Prampram ( } \mathbf{)}\end{array}$ \\
\hline Minimum & 100 & 100 \\
\hline Maximum & 350 & 300 \\
\hline Sum & 9000.10 & 5000.15 \\
\hline Mean & 210.163 & 150.15 \\
\hline Std. Deviation & 580.51 & 430.49 \\
\hline Total $(\mathrm{N})$ & 430 & 340 \\
\hline
\end{tabular}

Source: Author, 2021.

Most of the sampled households (59.7 percent) have been receiving remittances for a period of two to four years with 40.3 percent receiving remittances for more than four years (see Table 5). However, it is noted that more Akuapem households (48.8 percent) have benefited from remittances over a longer period compared to their GaAdangme counterparts (29.4 percent). This was attributed to traditions that require members of the matrilineal group to assist in the education and care of their siblings, nephews, and nieces. This view is consistent with the observation by Middleton (1979) on social support practices amongst the Akuapems and Sanders (2003) view on the dependence on remittances by rural farm households in Africa. Also, the study revealed that most households (60.5 percent) in Akuapem North receive monthly remittances compared to quarterly remittances (61.7 percent) in Shai-Osudoku and Ningo-Prampram districts (see Table 5). This is consistent with the matrilineal norms that require migrants to visit or remit their kin regularly to indicate their care and

${ }^{3}$ There is a possibility that these numbers have been under reported due to fear of taxation or poor financial record keeping. 
support. The patrilineal ethnic identity portrayed by a weaker commitment to sociocultural and economic ties among the Ga-Adangme was mentioned as the possible explanation for this pattern (Assan, 2008).

\section{Ethnicity and the shaping of Options and Utilisation of Remittances}

It was identified that remittances are used for the following purposes: consumption, investment, purchase of land, savings, dowries, and loans (see Table 5). Over half (51.9 percent) of the recipients of remittances in the sample indicated that they use a greater part of all the remittances on household consumption. Such consumption needs include the purchase of food items, paying school fees, medical bills, utility bills, purchasing of clothing. Most of the recipients of remittances in Akuapem North (67.4 percent) use them in meeting their consumption needs. On the contrary, most of the Ga-Adangme households (64.7 percent) indicated that they use their remittance for investment followed by consumption (see Table 6).

Table 6: Use of remittance income

\begin{tabular}{|l|c|c|c|c|c|c|}
\hline \multirow{2}{*}{\begin{tabular}{c}
\multirow{2}{*}{$\begin{array}{c}\text { Use of } \\
\text { remittances }\end{array}$} \\
\cline { 2 - 6 }
\end{tabular}} & \multicolumn{2}{|c|}{ Akuapem North } & \multicolumn{2}{c|}{$\begin{array}{c}\text { Shai-Osudoku and } \\
\text { Ningo-Prampram }\end{array}$} & $\begin{array}{c}\text { Total } \\
\text { frequency }\end{array}$ & $\begin{array}{c}\text { Total } \\
\%\end{array}$ \\
\cline { 2 - 6 } Mainly Consumption & 29 & 67.4 & $\mathrm{II}$ & 32.4 & 40 & 51.9 \\
\hline $\begin{array}{l}\text { Investment, } \\
\text { Consumption \& } \\
\text { Loans }\end{array}$ & 12 & 27.9 & 22 & 64.7 & 34 & 44.2 \\
\hline Savings \& Dowry & 2 & 4.7 & $\mathrm{I}$ & 2.9 & 3 & 3.9 \\
\hline Total & 43 & 100.0 & 34 & 100.0 & 77 & 100.0 \\
\hline $\mathrm{P}=0.002$ & & & & & & \\
\hline
\end{tabular}

Source: Author, 2021.

The Akan culture of children meeting the consumption needs of parents was considered to be the basis for this pattern. The sample in Akuapem North narrated a pattern of increasing supply of essential food, medicine, and clothing by migrants to their respective households. Aunty Ama, a 54-year-old household head in Akuapem North with a migrant son and daughter, cited her own experience and said:

It is considered [the] children's responsibility to ensure we have good health and not hungry by our Akan culture, so they send us food and medicine which are not available in the shops in this community. We receive food items like milk, corned beef, cornflakes, and rice, etc. Well, I will say we eat better than our neighbours who are not that fortunate.

The investment in housing development particularly among the Ga-Adangmes was cited as an attempt by migrants to improve their social status and that of their families as a result of cultural demands. Housing quality as well as the type of materials used in the construction of the building, are vital indicators of wealth and status in both ethnic groups but particularly among the Ga-Adangmes. According to Mr. Adjette, a 58-year Ga-Adangme household head with a migrant son, the culture in Shai-Osudoku and Ningo-Prampram districts encourages the acquisition of physical assets, which is an indicator of social status. He explained that: 
...the type of dwelling of a household is a significant subject of status in our ethnic group, and most households and migrants try to improve their housing conditions through remittances. I have therefore used most of the remittance income to repair my present abode and have constructed two bathrooms and a toilet for my family. Also, the type of roof over a house is used as a measure of wealth, so I replaced the thatch roof of my house with aluminum sheets which is very impressive.

The household interviews revealed that the outward appearance of individuals is traditionally used as a measure of wealth in both study districts but more especially among the Ga-Adangmes. As a result, remitting the rural household through the supply of clothing enhances its member's appearance, presentation, and status and is consistent with Bates views (2000).

Although remittances are mostly transfers between individuals and their households, some migrants, especially the Akuapems in Accra were reported to have formed ethnic associations and community development groups to raise money for development projects in their home communities (Anarfi et al. 2003). A typical example is the renovation and construction of a community primary school in Akuapem North and a community toilet in Shai-Osudoku and Ningo-Prampram districts. The study was informed that leaders of such associations tend to be elected to the Community Development Council to serve as advisors to the chief of their hometowns. This reflects observations of Lassen and Lileor (2006) in East Africa.

In both the districts, remittances received by households are used to pay the dowries for sons and nephews (3.9 percent), as demanded by the tradition in both study areas. It is customary to pay dowry before the bride joins the husband. The Dangmes have elaborate marriage ceremonies, which compels migrants and their families to engage in silent competitions. According to a female youth leader, marriage has, become a financially motivated activity rather than a socio-cultural activity. She said, "we see an increase in the number of single female youths of a marriageable age because the men cannot afford the amounts demanded by the in-laws". This pattern is believed to have led to the rising incidence of cohabitation, which is traditionally considered a cultural taboo in both the study districts. These views suggest that the receiving of money from migrants could have diverse impacts on existing social and cultural values which define the identity of the particular ethnic groups. The respondents in Akuapem North emphasized the social expectation of migrants helping their siblings and kins to join them in their respective urban destinations. Although this pattern is common in both ethnic groups, it is more prevalent amongst the Akuapems, given their matrilineal customs.

\section{Discussion}

This article has provided evidence to demonstrate the effect of migration and remittances as adaptations within peasant-based economies, which could vary with ethnicity and cohesion within structural socio-cultural groups. The empirical results presented here suggest that ethnicity, and more broadly birth-based identity, such as caste, can help create and support important economic transactions and shape the 
distribution and utilization of resources (remittances) in ways that would otherwise not be realized. The patterns of sending and the utilization of remittances are shaped by the ethnic backgrounds of migrants and remitted households.

Social and economic policy frameworks on endogenous development strategies could look beyond migration and remittances and incorporate migrants' ethnicity/ identity. Such an effort will be endogenous to specific groups and contribute to their development (Mazzucato, 2008; Thieme, 2006). An important theoretical implication of this study is that like many forms of birth-based social constructs and structures such as ethnic identity and caste, lower groups have often been portrayed in a very negative connotation, and their status within that classification is used as a tool of oppression. Such patterns especially tend to be the case for those in more deprived groups.

However, evidence from our study shows that different birth-based identity groups can employ their human capital and social agency to develop coping and survival methodologies and adaptation systems that enable them to overcome the very structures that seem to prevent their social mobility, development, and assimilation. It is therefore imperative to develop a systematic understanding of how such an agency could be enhanced deprived of birth-based groups, such as ethnic, cultural, and caste systems. This will ensure that beyond formal policies and regulations, identity and birth-based marginalized groups could also be socially and economically empowered. For this to occur sustainably, there is also the need to nurture and advance informal strategies that have and continue to allow marginalized birth-based groups to thrive, enhance social capital and overturn imposed social, economic, as well as religious structures.

Nevertheless, the use of digital money transfers through phones, mobile banking, and bus delivery services by the Ghana Private Road Transport Union (GPRTU) are areas where continued policy improvements could bring about much-needed change for many migrants. Further, simplified bank transfers that allow migrants to set up savings accounts and send remittances will make a significant impact. It is also essential for the policy officials of the Ghana Ministry of Women, Gender and Social Protection to provide informal livelihood training programs and hostel facilities to young migrants. This will enable young female migrants from marginalized ethnic groups particularly, to have more improved welfare, livelihood, and human security, especially during times like the Covid-19 pandemic.

Using case studies from Suriname, in the Carribbean, St-Hilaire (2010) argues the importance of groups' identity and assimilation in the development of a nation's economic and demographic strength. Supporting minority ethnically deprived young migrants has the potential to enhance the social mobility and economic development of both local and regional social economies and livelihoods. Achieving this across Africa and other regions of the world will also require the dismantling of historically entrenched and structural ethnic divisions which underline economic activities and institutional structures in many countries. Sustainable restructuring and assimilation will also require formal financial assistance for marginalized migrant-ethnic groups operating informal sector livelihoods and economic activities.

Policymakers in Africa and those working with the international and multilateral sector must also not lose sight of the over 40 percent of the population in Africa that lives in extreme poverty and depends on an informal economy with 84 percent of its MSMEs unregistered and uninsured (Ratha, 2021). The findings of this study 
support empirical evidence from Mexico (Taylor and Mora, 2006; Lassen and Lileor, 2006), East Africa, South Africa, and Lesotho (Waddington, 2003), which suggests the progressive reduction of relative poverty and changes in social structure and patterns between households and communities over time due to remittances.

It is also critical to address issues of intersectional discrimination that are often experienced by individuals from minority ethnic groups (Amnesty International, 2021). Several young migrants, including those from our study, are paid less due to their ethnicity, gender, and educational level compared to individuals with the same demographic characteristics from other ethnic groups. Addressing such patterns of intersectional discrimination will significantly enhance the income potential and abilities of young migrants as well as people from discriminated ethnic, caste, and other marginalized groups. This would help them to support themselves and their dependents. They will also be able to obtain assets and further invest in their livelihoods and household/personal well-being.

\section{Conclusion}

This article contributes to the debate on birth-based identity resource allocation and endogenous development through internal migration and how the associated remittances are utilized for welfare and livelihood development. The Covid-19 crisis has exacerbated economic hardships and may push up to 40 million Africans into extreme poverty (Brookings, 2021). The necessity of obtaining remittances in a stagnant economy, coupled with underemployment and unemployment, facilitates socio-cultural transformation in two traditional ethnic societies in southern Ghana.

The study shows how different ethnic groups adopt diverse patterns of movement and remittances based on ethnic values and birth-based cultural identities, which are endogenous to these groups. It is evident that having the agency to formulate, associate, and adapt, individuals and groups from marginalized ethnic, birth-based, and refugee groups could develop systems and assimilation processes that would facilitate their social and economic integration and advancement (Makovsky, 2019).

Woo et al. (2019) argue that racial and ethnic identity does not provide universal protection nor exacerbate the degree of psychological exposure and the effects of discrimination an individual may experience. However, they posit that whether it lessens or deepens the mental stress of discrimination may be contingent on its level and ethnicity. This suggests that the effects of birth-based identities may not be uniform. Policy officials, therefore, need to take this into account when designing interventions and protocols to address such patterns in our societies. There is the need to further examine the extent to which ethnicity, caste, and the broader forms of birthbased discrimination cause young people to experience the diverse mental health, economic and social burdens within such structured and discriminated migrant groups.

Discrimination based on work and descent is, unfortunately, a global phenomenon and affects millions of people in several societies in Africa, Asia, and the diaspora (Krishnaswami \& Krishnamurthi, 2021). Examining and addressing its impacts will therefore transform and expedite social and economic equity globally and improve the well-being of individual migrants from minority ethnic and caste-based societies. 


\section{References}

Agyepong, I.A., Wellington, E.K., Abbey, M.A. (1997). A comparative study of clinical and socio-cultural aspects of anaemia among adolescent Girls in rural Ghana. Acta Tropica 65, pp. 123-138.

Akuapem North District. (2001). The Akuapem North District Profile. Akropong: Ghana Ministry for Local Government and Rural Development.

Alesina, A., and La Ferrara, E. (2000). Participation of heterogeneous communities. Quarterly Journal of Economics, 111(3), pp. 847-904.

Amnesty International (2021) Overview, Retrieved on $7^{\text {th }}$ November 2021 from: https://www. amnesty.org/en/what-we-do/discrimination/

Anarfi, J.K. (1993). Sexuality, migration and AIDS in Ghana: a socio-behavioural study, Health Transition Review. Vol. 3, pp. 1-22.

Assan, J.K. and Khrisma, D. (2019). Political economy of internal migration and laborers seeking behavior of poor youth in Ghana. Ghana Studies, 22 (In Press).

Assan. J.K., Kharisma, D. and Adaboh, A.A. (2018). Demographic characteristics, migration and employment-seeking behavior: a case study of Ghana. In T. Binns, K. Lynch, and E. Nel (Eds.), The Routledge Handbook of African Development. London: Routledge, pp. 71-91.

Assan, J.K. (2008). Generational differences in internal migration: derelict economies, exploitative employment and livelihood discontent. International Development Planning Review, 30(4), pp. 377-398.

Baah, A.Y. (2001). The economy of Ghana. In The Social Dimension of Structural Adjustment in Ghana, ed. A.Y. Baah, Hallow, Accra.

Bates, R.H. (2000). Ethnicity and development in Africa: a reappraisal, The American Economic Review, 90(2), pp. 313-334.

Benneh, D. (1971). Land tenure and land use systems in forest-Savannah contact zone in Ghana: a case study. In I.M. Ofori (Ed.), Factors of Agricultural Growth in West Africa. Accra: ISSER.

Benneh, G. (1979). Ghana's agricultural development and the impact of government policies since the sixties. Library of Congress Paper, African Section.

Black, R. (2004). Migration and pro-poor policy in Africa. Sussex Migration Working Paper C6. Brighton: Sussex Centre for Migration Research.

Brookings Institution (2021). Foresight Africa, Brookings African Growth initiative, Washington DC.

Contzen, S. and Müller-Böke, U. (2014). How to identify 'target groups': consideration from Honduras and Nepal? NCCR North-South.

Cilliers, J. et al., (2020). Impact of COVID-19 in Africa: a scenario analysis to 2030. Institute for Security Studies, Frederick S. Pardee Center for International Futures, and Gordon Institute of Business Science, July 2020.

Crossman, A. (2020). The concept of social structure in sociology. ThoughtCo, Aug. 27, 2020, Retrieved on $27^{\text {th }}$ March 2021 from https://www.thoughtco.com/social-structuredefined-3026594

Dangme West District of Ghana (2000-2004). The Dangme West District Profile. Dodowa: Ministry for Local Government and Rural Development.

Deshingkar P., and Anderson, E. (2004). People on the move: new policy challenges for increasingly mobile populations. Natural Resources Perspectives Number 92. Overseas Development Institute: London.

Dickson, K.B. and Benneh, G. (1988). A new geography of Ghana, Longman: Essex. 
Dictionary.com, (2021) "Race" vs. "Ethnicity": Why These Terms Are So Complex, Retrieved on $27^{\text {th }}$ March 2021 from https://www.dictionary.com/e/race-vs-ethnicity/?itm source=parsely-api

Ellis, F. (2003). Livelihoods approach to migration and poverty reduction, London, Paper Commissioned by DFID, UK.

Ghana Statistical Service (GSS) (2000). Ghana living standards survey: report of the fourth round, Accra: Ghana Statistical Service.

Goldscheider, C. (1987). Migration and social structure: analytic issues and comparative perspectives in developing nations, Sociological Forum, 2(4), pp. 674-696.

Krishnaswami, C. and Krishnamurthi, G. (2021). Title VII and Caste Discrimination, Harvard Law Review, 134, F-456.

Henze, R.. (2005). Little Sisters: an exploration of agency, cultural borderlands and institutional constraints in the lives of two teenage girls. Social Justices 22nd September.

Hickey, S., and Mohan, G. (2005). Relocating participation within a radical politics of development. Development and Change, 36(2), pp. 237-262.

Hugo, G. (1981). Village-Community ties, village norms and ethnic and social networks: a review of evidence from the Third World. In G. De Jong. and R. Gardne (Eds.), Migration Decision Making. New York: Pergamon Press.

La Ferrara (2003). Kin group and reciprocity: a model of credit transaction in Ghana, The American Economic Review. Vol. 93(5), pp. 1730-1751.

Lamphere, L. (2007). Migration, assimilation and the cultural construction of identity: Navajo Perspectives, Ethnic and Racial Studies, 30(6), pp. 1132-1151.

Lassen, D.D., and Lilleør, H.B. (2006). Ethnic Diversity and Investment in Human Capital. Paper presented at the CSAE conference, the University of Oxford, March 19-21, 2006.

Levittt, P. (1998). Social Remittances: Migration driven local-level forms of cultural diffusion. International Migration Review, 32(4), pp. 926-948.

López-Anuarbe, M. \& Amparo Cruz-Saco, M. \& Park, Y. (2016). More than altruism: cultural norms and remittances among Hispanics in the USA. Int. Migration \& Integration, 17, pp. 539-567.

Lucas, R.B.E and Stark, Oded (1985). Motivations to remit: evidence from Botswana. The Journal of Political Economy, 93(5), pp. 901-918.

Makovsky, A. (2019). Turkey's Refugee problem: tiptoeing towards integration. Center for American Progress (CAP). Retrieved on $7^{\text {th }}$ November 2021, from https://www. americanprogress.org/article/turkeys-refugee-dilemma/

Mamala, P.D., Nikarthil, D., Irudayam, A., Vincent, M. and Dandge R. (2019). Discrimination based on work and descent and untouchability: global profile and a common framework to eliminate the practice, Asia Dalit Rights Forum, The Inclusivity Project, Amnesty International. Retrieved on $7^{\text {th }}$ November 2021, from http://www.ncdhr.org.in/wp-content/ uploads/2019/05/Discrimination-Based-on-Work-and-Descent-and-Untouchability.pdf

Marquette (2007). Path to development or road to nowhere? A livelihood approach to poverty, Labour Migration and Environment Links in Rural Areas of development Countries. paper prepared for the International PRIPODE Colloquium, UNESCO, Paris: 21 - 23 March 2007.

Mazzucato, V. (2008). The double engagement: transnationalism and integration. Ghanian migrants' lives between Ghana and The Netherlands. Journal of Ethnic and Migration Studies. Vol. 34(2), pp. 199-216.

Mendola, M. (2006). Rural out-migration and economic development at the origin: what do we know?. Sussex Migration Working Paper No 40.

Middleton, J. (1979). Home-Town: a study of an urban centre in Southern Ghana. Africa, 49(3). 
Miguel, E. and Gugerty, M.K. (2005) Ethnic diversity, social sanctions and public goods in Kenya. Journal of Public Economics, 89, pp. 2325-2368.

Mompati, T. and Prinsen, G. (2000). Ethnicity and participatory development methods in Botswana: some participants are to be seen and not heard. Development in Practice, 10(5), pp. 625-637.

Phoenix Library (2008). Resources on ethnic identity and diversity, Retrieved on $25^{\text {th }}$ July 2020 from www.pc.maricopa.edu/departments/library/guides/DivesityEthnic.html

Piesse, J. (2003). The socio-economic impact of remittances on poverty reduction. In: International Conference on Migrant Remittances. London: DfID /World Bank.

Portes, A. and Manning, P. (1991). The immigrant enclave: theory and empirical examples. In N. Yet (Ed.) Majority and minority: the dynamics of race and ethnicity in American life. Boston, MA.: Allyn and Bacon, pp. 319-332.

Root, B.D., and De Jong, G.F. (1991). Family migration in a developing country. Population Studies, 45, pp. 221-233.

Reddy, D.S. (2005). Ethnicity of caste. Anthropological Quarterly. Vol. 78(3), pp. 543-584.

Sander, C. (2003). Migrant remittances to developing countries: overview and introduction to issues for pro-poor financial services. DFID Research Paper. London. DFID.

St-Hilaire, A. (2010). Ethnicity, assimilation and nation in plural Suriname. Ethnic and Racial Studies, 24(6), pp. 998-1019.

Taylor, J.E., and Mora. J. (2006). Does migration reshape expenditures in rural households? Evidence from Mexico. World Bank Policy Research Working Paper_Washington, D.C., The World Bank.

Thieme, S. (2006). Social networks and migration: Far West Nepalese labourers migrants in Delhi, New Jersey: Transaction Publishers.

Dilip Ratha et al. (2020). Phase II: COVID-19 crisis through a migration lens. World Bank Group. Migration and Development Brief 33.

Ratha, D. (2021). Keep remittances flowing to Africa. In foresight Africa 2021. Brookings Institution, Washington DC.

Tsegai, D. (2007). Migration as a household decision: what are the roles of income difference? Insights from the Volta Basin of Ghana. The European Journal of Development Research, 19(2), pp. 305-326.

van der Geest K. (2003). Rural migration and livelihood security in Ghana. Sussex Migration Working Paper. Sussex Centre for Migration Research: Brighton.

Waddington, C. (2003). Livelihood outcomes of migration for poor people. Development Research Centre on Migration, Globalisation and Poverty. Brighton, UK, University of Sussex.

Winkels, A. and Adger, N. (2002). Sustainable livelihoods and migration in Vietnam: the importance of social capital as access to resources. International Symposium. Sustaining Food Security and Managing Natural Resources in Southeast Asia. Challenges for the 21st Century Chiang Mai, Thailand.

Woo, B., Fanb, W., Tranc, T.V., Takeuchic, D.T. (2019). The role of racial/ethnic identity in the association between racial discrimination and psychiatric disorders: a buffer or exacerbator? SSM - Population Health, 7.

Yinger, J.M. (1994). Ethnicity: source of strength? source of conflict? Albany: State University of New York.

Zhou, M. (1997). Segmented assimilation: issues, controversies and recent research on new second generation. International Migration Review, 31(4), pp. 975-1008. 